\title{
Tiger Nut as A Functional Food, Pharmacological and Industrial Agent: A Mini Review
}

\author{
Abiola F. Adenowo ${ }^{1 *}$ and Mutiu I. Kazeem ${ }^{2}$ \\ ${ }^{1}$ Department of Medical Biochemistry, Faculty of Basic Medical Sciences, Lagos State University College of Medicine Ikeja, Lagos, Nigeria. \\ ${ }^{2}$ Department of Biochemistry, Faculty of Science, Lagos State University, Ojo, Lagos Nigeria.
}

Received $16^{\text {th }}$ February, 2020, Accepted $2^{\text {nd }}$ May, 2020

DOI: 10.2478/ast-2020-0004

*Corresponding author

Abiola F.Adenowo E-mail: abiola.adenowo@lasucom.edu.ng, afaatimah@yahoo.com

Tel: +2348086987387

\begin{abstract}
Tiger nut is a plant generally underutilized in many parts of the world where it grows mostly as a weed. It is loved by children and many adults for its milky sugary taste, without most consumers being aware of its nutritional and health benefits. The level of awareness on the importance of this wonderful and greatly enriched plant is indeed very low. This review is aimed at expounding some of the advanced scientific researches which authenticated the folk reports on the therapeutic potential of the plant. Research findings which present potential application of this wonderful plant in food industry, pharmaceutical formulation, agricultural production and biofuel generation are also elucidated.
\end{abstract}

Keywords: Tiger nut; phytochemicals; antioxidants; biofuel; aphrodisiac. 


\subsection{Introduction}

Tiger nut (Cyperus esculentus) is a creeping perennial plant which belongs to the sedge family (Cyperaceae). It is commonly found populating wet marshes as well as stream and pond edges, where it grows in rough tufts (Arafat et al., 2009; Coskuner et al., 2002). It is an ancient plant commonly propagated in West Africa and South Europe. It produces sweet tubers that are consumed freshly or roasted. It can also be processed to obtain juice for beverage production and as animal feed (Udeozor, 2012). The tasty tubers from the plant has a length of $1-2 \mathrm{~cm}$, with asymmetrical shape when dry and egg-like or round shape upon getting soaked in water (Coskuner et al., 2002). The structure of tiger nut is shown (Figure 1).

This plant is naturalized and cultivated in many parts of the world including Spain, Turkey, Thailand, India, Sierra Leone, Ghana, Togo, Mali, Senegal, Niger and Nigeria (Oyedepo and Odoje, 2014; Asante et al., 2014). It is known by many other names including chufa, zulu nut, edible galingale, yellow nutgrass, yellow nutsedge, earth chestnut, rush nut, edible rush as well as ground almond. Tiger nut is known by several names in Nigeria based on the various ethnic groups such as 'aya' (Hausa), 'aki-Hausa' (Igbo) and 'ofio' (Yoruba). (Bamishaiye et al., 2010; Adejuyitan, 2011; Ekeanyanwu and Ononogbu, 2010). Three varieties of the plant grow in Nigeria - the brown, black and yellow varieties. The yellow variety is larger in size, more attractive in colour and fleshy (Chukwuma et al., 2010).

Tiger nut consumption is regarded in some countries as treatment for dysentery, indigestion, flatulence and mouth ulcer. Additionally, there are claims that regular consumers of tiger nut might not suffer health complications such as diabetes, cardiovascular diseases, hyperlipidemia, prostate cancer, colon cancer, hernia, fibrosis, and abnormal menstruation. It also improves fertility in both male and female (Government of Ghana official portal).

This review attempts to integrate available information on the chemical composition and pharmacological potential of tiger nut. Its application in the food, pharmaceutical and agricultural industries is also espoused.

\subsection{Chemical composition of tiger nut}

Several studies affirmed that tiger nut is highly nutritious with virtually all the nutrients required for good growth and development of both old and young. Proximate composition analysis showed that tiger nut is packed with carbohydrate and fibre needed for proper digestion (Figure 2) (Adejuyitan, 2011; Ekeanyanwu and Ononogbu, 2010; Monago and Uwakwe, 2009; Arafat et al., 2009). All varieties of this plant are rich in essential minerals such as calcium, magnesium, sodium, phosphorous, and potassium, required for various metabolic processes in the body (Table 1) (Ekeanyanwu and Onogbugbu, 2010). It also contains vitamins $\mathrm{A}, \mathrm{C}$, and $\mathrm{E}$ as well as various amino acids (Ekeanyanwu and Onogbugbu, 2010; Shaker et al., 2009). Numerous reports have also indicated that $C$. esculentus oil has abundant saturated and unsaturated fatty acids (Yeboah et al., 2012; Muhammad et al., 2011; Eteshola and Oraedu, 1996).

The raw tuber has low amount of antinutrients such as saponins, tannins, oxalates, phytate, and cyanogenic glycosides in comparison with other fruits, nuts, vegetables and tubers. As such, the concentration of antinutrients present in the tuber is acceptable for consumption (Ezeh et al., 2014; Okafor et al., 2003). Report of preliminary investigation by Chukwuma et al., (2010) on the acute toxicity of tiger nut extract in experimental rats showed that the aqueous extract produced no toxicity in the animals at all concentrations tested. Phytochemical analysis reports showed that tiger nut is composed of alkaloids, flavonoid, sterols, saponins, tannins which are reported to be responsible for various biochemical activities of the plant (Imam et al., 2013). These findings indicated that tiger nut is rich in important phytochemicals and generally save for consumption.

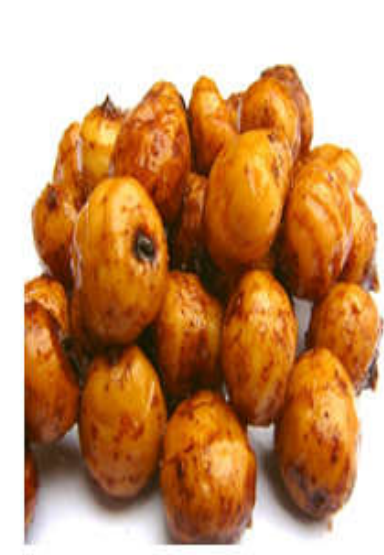

(a)

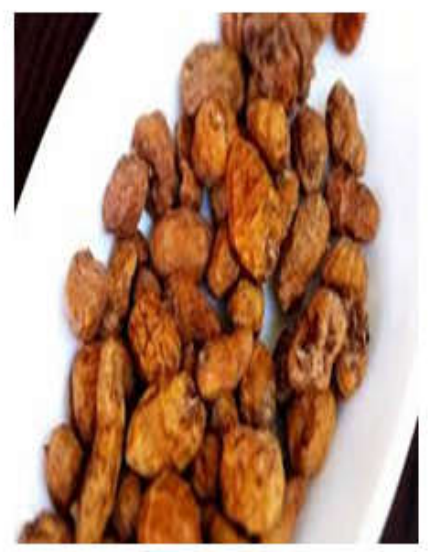

(b)
Figure 1: Cyperus esculentus L. (a) Fresh tuber (b) Dried tuber. 

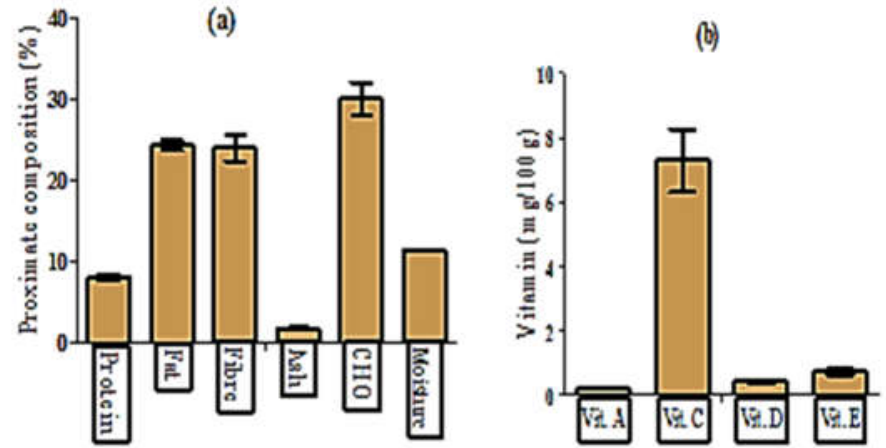

Figure 2: Proximate (a) and vitamin(b) composition of raw tiger nut flour. (Source: Ekeanyanwu and Ononogbu (2010))

\subsection{Pharmacological potentials of tiger nut}

Several studies have reported multiple pharmacological potentials of the tiger nut in different pathological conditions. These are summarized in Table 2.

\subsection{Hepatoprotective activity of tiger nut}

A study indicated that tiger nut exhibited a potential hepatoprotective action in experimental rats. Hepatotoxicity was induced in the rats through the intraperitoneal administration of carbon tetrachloride ( $\left.\mathrm{CC}_{4}\right)$ leading to remarkable elevations of liver marker enzymes aspartate and alanine transaminases, alkaline phosphatase as well as lipid peroxides. Pre-treatment of experimental rats for twenty-one days prior $\mathrm{CC}_{4}$ administration induced a significant reduction in the concentration of liver serum enzymes (Oyedepo and Odoje, 2014). Their result suggests that $C$. esculentus might provide protection against liver damage in rats. This result supports folkloric claim that tiger nut is a potent liver tonic.

\subsection{Anti-sickling action of tiger nut}

In vitro evaluation of the anti-sickling action of $C$. esculentus showed that methanol and aqueous extracts of tiger nut exhibited significant inhibition of the Haemoglobin-S (Hbs) gelatination. However, the methanol extract showed better anti-sickling property. This study revealed C. esculentus might be relevant in nutritionally-based therapeutic management of sickle cell patients (Monago and Uwakwe, 2009). This anti-sickling activity might be attributed to the presence of essential mineral such as iron and phosphorus as well as the presence of vitamin $\mathrm{C}$ and $\mathrm{E}$ in the plant. This finding buttress traditional claims that tiger nut milk is good for boosting of blood levels.

\subsection{Aphrodisiac potential of tiger nut}

Agbai and Nwanegwo, (2013) investigated the effect of C. esculentus on male reproductive hormones and some other androgenic parameters in mature male rats. Administration of methanol extract of tiger nut to Wistar rats elicited a significant increase in plasma level of male reproductive hormones as well as androgenic parameters in a dose dependent pattern.

Similarly, the report of Essawe and Almashhadani, (2010) established a link between the oral administration of tiger nut extract and sperm parameters in prepubertal mice. The experimental mice were treated with alcohol extracts of tiger nut for six weeks, which caused significant enhancement in the concentration and motility of the sperm. This finding is corroborated by the study of Oguike et al., (2008), in which the extract induced a significant effect on semen volume, testis weight, testis length and circumference, length of epididymis well as the overall weight of reproductive tract of matured experimental rabbits administered with the plant extract.

Al-Shaikh et al., (2013) also investigated the influence of $C$. esculentus tuber extract on reproductive abnormalities induced by the intraperitoneal administration of lead acetate. They reported that the extract relatively improved histopathological abnormalities in the testis of experimental rats. They concluded that the observed improvement might be due to the effect of the extract acting as an antioxidant or by instigating changes in sex hormones.

Results from the above studies suggested that tiger nut has a vital role to play in male reproductive functioning, as it improves the male reproductive parameters and protect it from any assault. This may be due to the chemical and phytochemical composition of tiger nut which confers antioxidant activity on the tissues.

\subsection{Antioxidant effect of tiger nut}

Oloyede et al., (2014) studied the antioxidant action of some extracts of $C$. esculentus. Both hexane and methanol extract exhibited strong antioxidant activity which is evidently comparable to standard antioxidant agents (ascorbic acid, $\alpha$-tocopherol, and butylatedhydroxylanisole [BHA]). They opined that the observed radical-scavenging action of the plant may be linked to the occurrence of phytochemicals like flavonoids and phenolics in the plant. A similar study on the effect of tiger nut oil from Xinjiang China, on female experimental mice indicated that the oil displayed significant free 
radical scavenging as well as antioxidant activity (Jing et al., 2013). Recently, much emphasis has been placed on the importance of plant materials in management of oxidative stress related diseases, it is pertinent that efforts are made towards production of nutraceutical agents from tiger nut and other plant materials after adequately confirming their efficacy.

\subsection{Antimicrobial action of tiger nut}

Adeniyi et al., (2014) studied the antimicrobial efficacy of C. esculentus root, inflorescence and shoots in comparison with standard antimicrobial drugs. The ethanol extract was active against Salmonella typhi and the result obtained was similar to that of ciprofloxacin (standard). The study showed the high antimicrobial activity of the plant extract and isolation of the bioactive compounds from it might lead to the advancement of novel antibiotic agents against Salmonella typhi infections.

Hasan et al., (2013) also studied the effect of ethanol extract of tiger nut tubers on Escherichia coli-induced endometritis in experimental mice. After seven days of administration, the decreased levels of haematological parameters; packed cell volume (PCV) and haemoglobin level $(\mathrm{Hb})$, associated with endometritis showed significant improvement compared with the values upon induction. Conversely, the elevated concentration of white blood cells (WBC) due to bacterial invasion was also lowered after treatment with the extract. The results observed in the extract treated group is similar to that obtained in the group treated with the standard drug gentamicin (Hasan et al., 2013). This confirms the use of the leaves and tubers of tiger nut traditionally in the treatment of gastrointestinal infections.

\subsection{Anti-atherosclerotic activity of tiger nut}

A study investigated the effect of consumption of tiger nutsupplemented diet on atherosclerosis using apolipoprotein $\mathrm{E}$ knockout mice (ApoE-/-mice). The study revealed that feeding the mice with feeds containing tiger nut led to the reduction in growth of atherosclerotic lesion. The observed outcome was linked to a reduction in the quantity of monocytes and macrophages in the blood (Salem et al., 2005). This is an indication that the plant might be involved in the modulation of the amount and viability of inflammatory cells associated with atherosclerosis in the experimental mice.

\subsection{Anti-inflammatory and anti-arthritic action of tiger nut}

The anti-inflammatory, anti-convulsion and anti-arthritic potential of C. esculentus oil was investigated using Swiss albino rats. Administration of the oil caused a dose dependent anti-inflammatory effect on carrageenan-induced paw edema and decrease in extensor phase, clonus phase as well as stupor phase associated with convulsion (convulsion induced in the rats with maximal electroshock, MES). There was also a decrease in swelling on the hind paw of the rats due to induction of arthritis (by injection of formaldehyde) after treatment with doses of the oil as well as reduction of pain in the rat (determined by sum total of time spent on licking the paw injected with formalin) upon administration of the oil (Biradar et al., 2010). The result of this finding calls for further investigation to ascertain claims that consumption of tiger nut alleviates bone and joint pains.

There is need to study the biochemical and biological mechanisms which elicits the observed pharmacological activities. This may be by determining the effect of tiger nut on the expression of proteins and or genes associated with the pharmacological activities studied.

Table 1: Mineral composition of raw tiger nut flour

\begin{tabular}{lr}
\hline Mineral (mg/100g) & Composition \\
\hline Sodium (Na) & $34.3 \pm 1.53$ \\
Calcium (C) & $100.0 \pm 2.65$ \\
Iron (Fe) & $4.12 \pm 0.12$ \\
Zinc ( $\mathrm{Zn})$ & $3.98 \pm 0.31$ \\
Potassium (K) & $486.0 \pm 59.9$ \\
Magnesium (Mg) & $94.4 \pm 1.28$ \\
Copper (Cu) & $0.92 \pm 0.05$ \\
Magnesium (Mn) & $0.26 \pm 0.01$ \\
Phosphorus (P) & $219.0 \pm 10.0$ \\
\hline
\end{tabular}

Source: Ekeanyanwu and Ononogbu (2010) 


\subsection{Industrial uses of tiger nut}

\subsection{Tiger nut in food technology}

Tiger nut oil has a characteristic rich nutty taste and is comparable with other good oils like corn oil, cotton seed oil, soybean oil and olive oil. In terms of proximate composition and quality, it is a good substitute for these oils when there is scarcity. Tiger nut oil is also very suitable for salad dressing due to its ability to remain liquid even at refrigeration temperature (Bamishaiye and Bamishaiye, 2011). The cold-pressed oil from tiger nut tuber is highly recommended for cooking due to it resistance to chemical decomposition at extreme temperature. The oil is also ideal for cooking because it forms a crust on the surface of the food making less fat to be absorbed into the food (Ezebor et al., 2006).

In Spain, 'horchata de chufa' (tiger nut milk) is made from tiger nut tubers, this is the most popular application in food technology. This non-alcoholic beverage with milky appearance is of immense economic importance in the Valencian region of Spain. It is produced by soaking tiger nut tubers in water for about 8 hours, grinding the nut, pressing to extract the milky juice and mixing with sugar. The beverage 'Horchata' has become very popular in many nations including France, Portugal, Argentina, and United Kingdom (Sanchez-Zapata et al., 2012). Many researchers have studied the palatability and quality of milk beverages from tiger nut tuber, and their findings indicated that the milk is comparable to that from other sources including cow's milk (Bamishaiye and Bamishaiye, 2011; Belewu and Belewu, 2007; Sanful, 2009). Tiger nut is also used as an alternative milk source in yoghurt and other fermented products (Akoma et al., 2004).

Belewu and Abodunrin (2008) revealed that tiger nut is very useful in the production of 'Kunnu', a non-alcoholic beverage traditionally made with cereals such as sorghum and millet. The tiger nut based 'kunnu' was discovered to be relatively cheaper and more nutritious than the one made traditionally from sorghum and millet. Additionally, research shows that tiger nut tuber processed into flour has a distinctive sweet taste which makes it valuable for various confectionary purposes. Its high natural sugar content helps in avoiding the need to add excessive additional sugar. More so, the flour has no gluten and thus ideal for individuals that are allergic to gluten (Bamishaiye and Bamishaiye, 2011).

Another study on the chemical and beneficial properties of two varieties of Nigerian tiger nut flours showed that the flour protein content compares favourably with that of wheat flour. The flour also has adequate quantity of calcium required for teeth and bone formation in infants as well as iron content vital for formation of red blood cells. The low bulk density, setback and breakdown viscosity also make tiger nut flour ideal in food formulation without fear of retrogradation (Oladele and Aina, 2007). The nutritional potential, antioxidant profile, as well as the sensory qualities of biscuits prepared with various concentrations of tiger nut flour were investigated by Ahmed et al. (2014). Tiger nut - enriched biscuit showed higher fibre and fat content in comparison with the control. There were also increase in the levels of zinc and iron in the supplemented biscuit as well as lower level of sodium. In addition, there was great improvement in the antioxidant profile of the enriched biscuit (higher polyphenols and flavonoids). The sensory evaluation result also indicated the supplemented biscuit exhibited better qualities in terms of softness and moistness. These observations led to the conclusion that addition of tiger nut flour will enhance the health and nutritional values of the snack.

Ukwuru and co-workers formulated two novel products from tiger nut tuber namely; Orange tiger nut beverage (OTB) and Tiger nut drink (TD). The OTB was made of a mixture of orange juice and tiger nut milk while TD was dehydrated milled tiger nut tuber reconstituted into cold water. Both products were assessed for proximate composition, sensory and microbiological status. The proximate analysis revealed that the products were contained acceptable levels of carbohydrate, protein, ash, moisture and fat. Sensory evaluation indicated the products were scored high acceptability in terms of colour, aroma as well as taste with the OTB having the higher acceptability. The products were also confirmed wholesome based on microbiological analysis (Ukwuru et al., 2011). Therefore, tiger nut has a great potential for the production of nutritive and refreshing beverages for human consumption.

\subsection{Tiger nut in pharmaceutical industry}

A study isolated starch from the tubers of $C$. esculentus and evaluated its physicochemical and binding properties. Scanning electron microscopy showed that tiger nut starch is made up of elliptical particles with even surface as well as narrow particle size distribution which conforms to the United States Pharmacopeia standards. The moisture sorption and flow properties of the starch were also comparable with maize starch. Additionally, tiger nut starch has lower swelling power than potato and maize, indicating tiger nut starch offer outstanding binding properties without conceding drug release characteristics and would be vital in pharmaceutical formulation (Manek et al., 2012). 
Table 1: Pharmacological activities of Cyperus esculentus (Tiger nut)

\begin{tabular}{|c|c|c|c|c|}
\hline Activities & Model & Extracts & Results & Reference \\
\hline Hepatoprotective & $\begin{array}{l}\text { In-vivo } \\
\text { (Rats) }\end{array}$ & Flour & $\begin{array}{l}\text { Tiger nut supplemented diet ameliorate hepatic } \\
\text { damage }\end{array}$ & Oyedepo and Odoje, (2014) \\
\hline Anti-sickling & In-vitro & $\begin{array}{l}\text { Methanol, } \\
\text { Water }\end{array}$ & $\begin{array}{l}\text { Extracts have anti-HbS gelation activity especially } \\
\text { methanol }\end{array}$ & Monago and Uwakwe, (2009) \\
\hline \multirow[t]{3}{*}{ Aphrodisiac } & $\begin{array}{l}\text { In-vivo } \\
\text { (Rats) }\end{array}$ & Methanol & $\begin{array}{l}\text { Extract increases concentration of male } \\
\text { reproductive hormones like testosterone and } \\
\text { sperm counts }\end{array}$ & Agbai and Nwanego, (2013) \\
\hline & $\begin{array}{l}\text { In-vivo } \\
\text { (Mice) }\end{array}$ & Ethanol & $\begin{array}{l}\text { Significant increase in sperm concentration and } \\
\text { motility }\end{array}$ & $\begin{array}{l}\text { Essawe and Almashhadani, } \\
(2010)\end{array}$ \\
\hline & $\begin{array}{c}\text { In-vivo } \\
\text { (Rabbits) }\end{array}$ & Aqueous & $\begin{array}{l}\text { Improves semen volume and testis weight of } \\
\text { rabbits }\end{array}$ & Oguike et al., (2008) \\
\hline $\begin{array}{l}\text { Anti-reproductive } \\
\text { toxicity }\end{array}$ & $\begin{array}{l}\text { In-vivo } \\
\text { (Rats) }\end{array}$ & Ethanol & $\begin{array}{l}\text { Ameliorates histopathological damage in the testis } \\
\text { of lead acetate induced toxic rats }\end{array}$ & Al-Shaikh et al., (2013) \\
\hline \multirow[t]{2}{*}{ Antioxidant } & In-vitro & $\begin{array}{l}\text { Methanol, } \\
\text { Hexane }\end{array}$ & $\begin{array}{l}\text { Both extracts displayed significant antioxidant } \\
\text { activities compared to standards }\end{array}$ & Oloyede et al., (2014) \\
\hline & $\begin{array}{l}\text { In-vivo } \\
\text { (Mice) }\end{array}$ & Oil & The oil exhibited free radical scavenging abilities & Jing et al., (2013) \\
\hline \multirow[t]{2}{*}{ Antimicrobial } & In-vitro & Ethanol & $\begin{array}{l}\text { The extract inhibited the growth of Salmonella } \\
\text { typhi }\end{array}$ & Adeniyi et al., (2014) \\
\hline & $\begin{array}{l}\text { In-vivo } \\
\text { (Mice) }\end{array}$ & Ethanol & Ameliorates Escherichia coli induced endometritis & Hasan et al., (2013) \\
\hline Anti-atherosclerotic & $\begin{array}{l}\text { In-vivo } \\
\text { (Mice) }\end{array}$ & Flour & $\begin{array}{l}\text { Tiger nut supplemented diets reduced } \\
\text { atherosclerotic lesions }\end{array}$ & Salem et al., (2005) \\
\hline Anti-inflammatory & $\begin{array}{l}\text { In-vivo } \\
\text { (Rats) }\end{array}$ & Oil & $\begin{array}{l}\text { Displayed dose-dependent anti-inflammatory and } \\
\text { anti-arthritic activities }\end{array}$ & Biradar et al., (2010) \\
\hline
\end{tabular}

\subsection{Tiger nut in agricultural production}

The study of Onunkwo and Ugwuene (2015) demonstrated that tiger nut seed meal has good prospect as source of energy in the meal of broiler birds for good growth performance and economic viability at an inclusion of $75 \%$ dietary levels. Bamgbose and co-workers (2003) also showed that adding of $33.3 \%$ of tiger nut to the diet of cockerel starter marsh elicited an improvement in carcass yield as well as a reduction in the cost of feed consumed by the cockerel. Another study also investigated the nutritive value of alkaline-treated tiger nut meal (ATTNRM) in broiler chicken. The findings revealed that inclusion of $10 \%$ ATTNRM improved the growth of the chicken without producing any negative effect on their biochemical and haematological indices (Kwadwo et al., 2014). These reports indicate that the utilization of tiger nut in poultry diets will help poultry farmers to make animal protein available at a reduced cost and maximise their profit.
The effect of tiger nut-based meal on West Africa Dwarf (WAD) goats was studied by Belewu et al., (2007). Their result revealed that animals fed with tiger nut-based meals exhibited better weight gain and digestibility coefficient in comparison to the control. Inclusion of tiger nut in the meal of livestock animals will imperatively increase production and reduce cost. Oladele et al., (2010) also investigated the effect of replacing maize with tiger nut in the diet of catfish fingerlings (Clarias garepinus). Their findings revealed that the tiger nut meal enhanced the growth performance of the fish with no adverse effect on them, and suggested that the meal is an ideal replacement for maize meal in fishery in order to maximize output and minimize cost.

\subsection{Tiger nut as biofuel source}

Barminas et al. (2001) produced and characterised biofuel from tiger nut oil. The results indicated that trans-esterification of $C$. esculentus oil gave methyl and ethyl esters with similar fuel characteristics as 
biofuels such as soybean oil and jatropha oil. Hence tiger nut oil could be a viable alternative as renewable source of energy. A similar study also showed that methyl esters produced by tiger nut oil met the biodiesel customary prerequisites with the exception of cold filter plugging point and oxidation stability (Makareviciene et al., 2013). The yield and performance of various blends of tiger nut oil and petrodiesel was investigated by Ofoefule et al., (2013), and they reported that appropriate blend of the oils gave performance very close to petro-diesel. These results showed that aside from the environmentally friendly benefit of tiger nut as source of biofuel, its utilization will greatly reduce cost of energy production.

\subsection{Conclusion}

Plant species are of diverse importance in different aspect of human life, however many of these are greatly underutilized. The foregoing review expounds some of the great nutritional, nutraceutical, pharmacological, agricultural and biofuel potentials of tiger nut which needs to be exploited. There is a dire need to encourage and intensify scientific research towards identification of active constituents of tiger nut responsible for the identified pharmacological potentials. Additionally, food industries and agricultural sector needs to tap from the abundant nutritional values attributed to this plant. Deliberate cultivation of tiger nut should be encouraged among farmers to make its tubers readily available for consumption and other applications.

Conflict of Interest: The authors declare no conflict of interest. Authors contribution

Conception: AFA, MIK.

Design: AFA, MIK.

Execution: AFA, MIK.

Interpretation: AFA, MIK.

Writing of the paper: AFA, MIK.

\section{References}

Adejuyitan, J.A., 2011, Tigernut processing: its food uses and health benefits. American Journal of Food Technology, 6: 197-201.

Adeniyi, T.A., Adeonipekun, P.A., Omotayo, E.A., 2014, Investigating the phytochemicals and antimicrobial properties of three sedge (Cyperaceae) species. Notulae Scientia Biologicae, 6: 276-281.

Agbai, E.0., Nwanegwo, C.0., 2013, Effect of Methanolic Extract of Cyperus esculentus L. (Tiger nut) on luteinizing hormone, follicle stimulating hormone, testosterone, sperm count and motility in male albino wistar rats. Journal of Medical and Applied Biosciences, 5: 5261.

Ahmed, Z.S., Abozed, S.S., Negm, M.S., 2014, Nutritional value and sensory profile of gluten-free tiger nut enriched biscuit. World Journal of Dairy Food and Sciences, 9: 127-134.
Akoma, O., Elekwa, U.O., Afodunrinbi, A.T., Onyeukwu, G.C., 2004, Yogurt from coconut and tiger nuts. Journal of Food Technology in Africa, 5: 132-134.

Al Essawe, E.M., Almashhadani, A.A., 2009, The Effect of Cyperus esculentus on sperm function parameters in prepubertal mice as a model for human. Baghdad Scientific Journal, 7: 489-494.

Al-Shaikh, M.N., Wahab, T.A.A., Kareem, S.H.A., Hamoudi, S.R., 2013, Protective effect of Chufa tubers (Cyperus esculentus) on induction of sperm abnormalities in mice treated with lead acetate. International Journal of Drug Development \& Research, 5: 387-392.

Arafat, S.M., Gaafar, A.M., Basuny, A.M., Nassef, S.L., 2009, Chufa tubers (Cyperus esculentus L.): As a new source of food. World Applied Sciences Journal, 7: 151-156.

Asante, F.A., Oduro, I., Ellis, W.O., Saalia, F.K., 2014, Effect of planting period and site on the chemical composition and milk acceptability of tiger nut (Cyperus Esculentus L.) tubers in Ghana. American Journal of Food Nutrition, 2: 49-54.

Bamgbose, A.M., Eruvbetine, D., Dada, W., 2003, Utilization of tiger nut (Cyperus rotundus L.) meal in diets for cockerel starters. Bioresource Technology, 89: 245-248.

Bamishaiye, E.I., Bamishaiye, O.M., 2011, Tiger nut: as a plant, its derivatives and benefits. African Journal of Food, Agriculture, Nutrition and Development, 11: 5157- 5170.

Bamishaiye, E.I., Muhammad, N.O., Bamishaiye, O.M., 2010, Assessment of biological value of tiger nut (Cyperus esculentus) tuber oil meal-based diet in rats. Annals of Biological Research, 1: 274-278.

Barminas, J.T., Maina, H.M., Tahir, S., Kubmarawa, D., Tsware, K., 2001, A preliminary investigation into the biofuel characteristics of tiger nut (Cyperus esculentus) oil. Bioresource Technology, 79: 87-89.

Belewu, M.A., Abodunrin, O.A., 2008, Preparation of kunnu from unexploited rich food source: tigernut (Cyperus esculentus). Pakistan Journal of Nutrition, 7: 109-111.

Belewu, M.A., Belewu, K.Y., 2007, Comparative physico-chemical evaluation of tiger-nut, soybean and coconut milk sources. International Journal of Agriculture and Biology, 5: 785-787.

Belewu, M.A., Orisameyiti, B.R., Ajibola, K.A., 2007, Effect of feeding graded levels of tiger nut (Cyperus esculentus) seed meal on the performance characteristics of West African dwarf goat. Pakistani Journal of Nutrition, 6: 528-529.

Biradar, S., Kangralkar, V.A., Mandavkar, Y., Thakur, M., Chougule, N., 2010, Anti-inflammatory, antiarthritic, analgesic and anticonvulsant activity of Cyperus essential oils. International Journal of Pharmacy Pharmaceutical Sciences, 2: 123-125.

Coskuner, Y., Ercan, R., Karababa, E., Nazlican, A.N., 2002, Physical and chemical properties of chufa (Cyperus esculentus $\mathrm{L}$ ) tubers grown in the Cukurova region of Turkey. Journal of the Science of Food and Agriculture, 82: 625-631.

Chukwuma, E.R., Obioma, N., Christopher, O.I., 2010, The phytochemical composition and some biochemical effects of Nigerian 
tiger nut (Cyperus esculentus L.) tuber. Pakistan Journal of Nutrition, 9: 709-715.

Ekeanyanwu, R.C., Ononogbu, C.I., 2010, Nutritive value of Nigerian tigernut (Cyperus esculentus L.). Agricultural Journal, 5: 297-302.

Eteshola, E., Oraedu, A.C. I., 1996, Fatty acid composition of tiger nut tubers (Cyperus esculentus L), baobab seeds (Adansonia digitata L), and their mixture. Journal of American Oil Chemists' Society, 73: 255-257.

Ezebor, F., Igwe, C.C., Owolabi, F.A. T., Okoh, S.O., 2006, Comparison of the physico-chemical characteristics, oxidative and hydrolytic stabilities of oil and fat of Cyperus esculentus L. (yellow nutsedge) and Butyrospermum parkii (shea nut) from Middle-Belt State of Nigeria. Nigerian Food Journal, 23: 33-39.

Ezeh, O., Gordon, M.H., Niranjan, K., 2014, Tiger nut oil (Cyperus esculentus L.): A review of its composition and physico-chemical properties. European Journal of Lipid Science and Technology, 116: 83-794.

Government of Ghana official portal http://www.ghana.gov.gh 〈index.php/2012-02-08-08-327/features/5620-tiger-nuts Accessed 9/03/2015.

Hasan, H.F., Hamzah, A.M., Zghair, Z.R., 2013, The comparative effect between Cyperus esculentus seeds extract and gentamicin on induced endometritis in mice. JPCS, 7: 40-47.

Imam, T.S., Aliyu, F.G., Umar, H.F., 2014, Preliminary phytochemical screening, elemental and proximate composition of two varieties of Cyperus esculentus (Tiger nut). Nigerian Journal of Basic Applied Science, 21: 247-251.

Jing, S., Ouyang, W., Ren, Z., Xiang, H., Ma, Z., 2013, The in vitro and in vivo antioxidant properties of Cyperus esculentus oil from Xinjiang, China. Journal of the Science of Food Agriculture, 93: 1505-1509.

Kwadwo, O., Atuahene, C.C., Attoh-Kotoku, V., Adjei, M.B., 2014, The growth performance, carcass and haematological characteristics of broiler chickens fed alkaline-treated Tiger nut (Cyperus Esculentus) residue meal. Journal of Animal Science Advances, 4: 1068-1081.

Makareviciene, V., Gumbyte, M., Yunik, A., Kalenska, S., Kalenskii, V., Rachmetov, D., Sendzikiene, E., 2013, Opportunities for the use of Chufa sedge in biodiesel production. Industrial Crops Products, 50: 633-637.

Manek, R.V., Builders, P.F., Kolling, W.M., Emeje, M., Kunle, O.O., 2012, Physicochemical and binder properties of starch obtained from Cyperus esculentus. AAPS Pharmaceutical Science and Technology, 13: 379-388.

Monago, C., Uwakwe, A., 2009, Proximate composition and in vitro anti-sickling property of Nigeria Cyperus esculentus (tiger nut sedge). Trees of Life Journal, 4: 1-6.

Muhammad, N.O., Bamishaye, E.I., Bamishaye, O.M, Usman, L.A., Salawu, M.O., Nafiu, M. O., Oloyede, O.B., 2011, Physicochemical properties and fatty acid composition of Cyperus esculentus (tiger nut) tuber oil. Bioresearch Bulletin, 5: 51-54.
Oguike, M.A., Aboaja, C.U., Ukweni, I.A., Herbert, U., 2008, Influence of tigernut (Cyperus esculentus L.) on the semen characteristics and testicular parameters of rabbits. Bulletin of Animal Health and Production in Africa, 56: 67-77.

Oladele, A.K., Aina, J.0., 2007, Chemical composition and functional properties of flour produced from two varieties of tiger nut (Cyperus esculentus). African Journal of Biotechnology, 6: 2473-2476.

Oladele, A.K., Alatise, P.S., Ogundele, O., 2010, Evaluation of Tiger nut (Cyperus esculentus) meal as a replacement for maize meal in the diet of Catfish (Clarias gariepinus) fingerlings. World Journal of Agricultural Science, 6: 18-22.

Oloyede, G.K., Abimbade, S.F., Nwabueze, C.C., 2014, Antioxidant and toxicity screening of extracts obtained from Cyperus esculentus. Academia Arena, 6: 77-83.

Onunkwo, D., Ugwuene, M., 2015, Growth performance of broiler chicken fed varying levels of Tiger nut (Cyperus esculentus L.) seed meal. International Journal of Livestock Research, 5: 78-85.

Oyedepo, T.A., Odoje, O.F., 2014, Hepato-protective activities of tiger nut (Cyperus esculentus) against hepatotoxicity induced by carbon tetrachloride in rats. Journal of Pharmacology and Toxicological Studies, 2: 37-41.

Salem, M.L., Zommara, M., Imaizumi, K., 2005, Dietary supplementation with Cyperus esculentus L (tiger nut) tubers attenuated atherosclerotic lesion in apolipoprotein $\mathrm{E}$ knockout mouse associated with inhibition of inflammatory cell responses. American Journal of Immunology, 1: 60-67.

Sánchez-Zapata, E., Fernández-López, J., Angel Pérez-Alvarez, J., 2012, Tiger nut (Cyperus esculentus) commercialization: health aspects, composition, properties, and food applications. Comprehensive Review in Food Science and Food Safety, 11: 366-377.

Shaker, M.A., Gaafar, A.M., Basuny, A.M., Nassef, S.L., 2009, Chufa tubers (Cyperus esculentus L.): As a new source of food. World Applied Science Journal, 7: 151-156.

Udeozor, L.0., 2012, Tiger nut-soy milk drink: Preparation, proximate composition and sensory qualities. International Journal of Food and Nutritional Sciences, 1: 18-26.

Ukwuru, M.U., Ibeneme, C.L., Agbo, G.I., 2011, New product development from tiger nut (Cyperus esculentus) and their sensory, proximate and microbiological evaluation. Pakistani Journal of Nutrition, 10: 101.

Yeboah. S.O., Mitei, Y.C., Ngila, J.C., WessJohann, L., Schmidt, J., 2012, Compositional and structural studies on the oils from two edible seeds: Tiger nut, Cyperus esculentum, and Asiato, Pachira insignis, from Ghana. Food Research International, 47: 259-266. 